\title{
Anthropological Practices of Self-Care: Eventfulness of the Concept
}

\author{
Sergey A. Smirnov* \\ Novosibirsk State University \\ of Economics and Management \\ 52 Kamenskaya Str., Novosibirsk, 630099, Russia
}

Received 18.02.2017, received in revised form 04.12.2017, accepted 12.12.2017

The present article introduces the concept of anthropological practice as a special practice of transformation and change of a person. The concept is discussed in terms of cultural tradition known as the "self-care" practice. The concept of anthropological practice is regarded from different focuses, primarily from the topic of care: ontological tope, tope of care discourse, tope of care as a practice, tope of care object, tope of care subject. The present research hereby proposes a classification of anthropological practices, where different types of objects and subjects for anthropological practice of care are described from the perspective of this topic. As a result, five types of anthropological practices of self-care are described: "epistrophe", "agon", "mimesis", "cogito" and "autopoiesis". Each type means different identities for a subject of practice, different practices and different teloses, i.e. ultimate objectives of practice. Works of contemporary authors containing analysis and classification of self-care practices in the culture are reviewed.

Keywords: anthropological practice, self-care, topic of anthropological practice, subject of anthropological practice, epistrophe, agon, mimesis, cogito, autopoiesis.

The research is carried out within the framework of the project "Building non-classic anthropology. New human ontology", implemented at Novosibirsk State University of Economy and Administration with support from Russian Science Foundation (grand agreement № 14-18-03087).

DOI: 10.17516/1997-1370-0182.

Research area: philosophy.

How eventful is our life? Do any events happen on their own or are they somehow prepared? Is an event consequence of a coincidence, a game of blind spirits, or is an event caused by one's hands, mind and heart?

I believe that eventfulness of human life is a consequence of special care described in culture as care of the self $(\dot{\varepsilon} \pi \mu \varepsilon \dot{\varepsilon} \lambda \varepsilon 1 \alpha)$. The phenomenon of the care of the self has been known since long ago and is well-described in literature (Bezrogov, 2015; Ivanchenko, 2009; Pichugina, 2014, 2013a, 2014b; Pogoniaylo, 2007; Pogoniaylo, 2009; Smirnov, 2010; Khoruzhiy, 2010; 1998).

We understand care of the self as an anthropological practice of building and managing the human concept, the practice of

(C) Siberian Federal University. All rights reserved

* Corresponding author E-mail address: smirnoff1955@yandex.ru 
founding and cultivating the new "functional organs" required for anthropological navigation as such, as well as skills and abilities, personal features necessary for developing and controlling one's trajectory of life. Without these special functional organs, without "smart vision" and "smart body", it is impossible to build or follow any trajectory of life. It would be the same as going out to the open sea without a pilot chart and a navigation officer, or flying an airplane with all navigation instruments broken.

\section{Anthropological practice of care: phenomenon framework}

Reading his lectures on "Hermeneutics of the subject" at College de France in 1982, M. Foucault mostly cared for (which reminds us of care again) the fact that was the most important from his point of view: we, modern European intellectuals, have forgotten ourselves (Foucault, 2007). We need to reinterpret it all for ourselves and begin from scratch again. Foucault assumed that we have forgotten our actual human duty, which is to take care of ourselves.

Foucault associated care of the self with one's current situation and what is happening around a person. And as he believed, the things happening around were not good. Because, first of all, the human has forgotten himself. Secondly, he does not understand himself at all any more. For this reason, we need to re-start ourselves. And here is the point where Foucault turned to history.

But phenomenon did not turn into a concept but remained a phenomenon. Let's try to rely on the phenomenon itself and ask ourselves some framework questions, introduce some criteria and milestones for further analysis made in the form of framework topes, i.e. entities we fill with this or that content.

Tope on: ontological source of care. How ontologically enrooted is the self-care phenomenon? Does it act as an ontological milestone and support? What do modern researchers say and write about it? Do they go farther than their predecessors, are there too many problems and unexplored facts?

Tope two: discourse of care. What do we say, and how do we do it, speaking of self-care? What words do we use? What vocabulary do we develop to speak of our care phenomenon? Don't we lose the basic meanings in our rich and circumlocutory self-care talks? Have we preserved the cultural etymons of ontological meanings? Or is it not only the ontological source that is lost, but also our discourse and our vocabulary, exhausted and reduced?

Tope three: object of care. What is the object-orientation of this care? Where is the care object aimed? At itself, at the world, at the other? If at itself, then at what exactly within itself? At what qualities within itself is it aimed?

Tope four: subject of care. Who is the one taking care of himself? Is there a concorded and understood answer to the question of the subject of care? Who is the subject of care? Who is the one engaged in this care? Does the analysis of the care phenomenon from the point of view of its subject bring something new into the understanding of care phenomenon, or does it lead to the dead-end of the well-known contemplations of the subject and the author?

Tope five: care as practice (anthropological practice). What does a person do, taking care of himself? What does it mean from the practical point of view? What actions does it involve? What is the meaning of this action? May selfcare be described as a work, as a special practice, or, to be precise, an anthropological practice? Is this practice limited to a moral care of your fellow creature or is it a special ascetic practice assuming transformation of the one engaged in care of the self? What is the difference of selfcare from other practices? If it is different, it 
needs specific goals and tasks, types of activities and results. Or do we overload this phenomenon, trying to squeeze all richness of the practices into the underlying, but only one moral principle of one's responsibility of the fellow creature and, therefore, the responsibility of himself?

Now, let us elaborate on each of the topes. The result will be formulated as a conclusion of the four topes, revealing the sense of the phenomenon to its full.

\section{Tope one:}

\section{Ontological source of care}

If we want to understand this or that phenomenon, we need to understand its ontological source, which makes it what it is and extrudes it into its own being.

To enroot the phenomenon of care of the self, many authors turn to the heritage of M. Heidegger (Poliakova, 2015; Solov'iov, 2006; Fedicheva, 2010). For instance, M.A. Poliakova quotes an old fable by the Roman scientist and writer Julius Hyginus, also cited by the German philosopher in his "Being and Time" (Poliakova, 2015) 1 .

Roman writer and scientist Julius Hyginus practically turned to the ancient mythopoetic concept of birth of the anthropogenic world from the first man, whose parts of body were connected to the parts of the world (unity of micro and macrocosm). According to the fable, Cura (Care) picked some mud and shaped it, and then asked Jupiter to give it spirit. He gladly granted. Then the gods decided to name what they had created. They named it homo, for it is made of hummus (earth). This is how the first man was created.

This travelling story of a man created of earth, mud, "the dust of the ground", on one hand, and the divine breath on the other ("the Lord God $<\ldots>$ breathed into his nostrils the breath of life, and the man became a living being" (Genesis, 2,7) shows, as M. Heidegger claims, the archetypical genesis and basis of pre-ontological foundation of the phenomenon of care. That is how Adam was created. Then M. Heidegger substantiates the idea of care as a component of his philosophic concept of being as presence. He sees care as an "existential and basic ontological phenomenon" (Heidegger, 1997: 196). For the German philosopher, care acts as an ontological "being in presence", which, actually, is what a human is, i.e. Dasein. Therefore, for M. Heidegger care is not a feature of psychological or moral obligation of a subject to himself or another person. Care is an ontological feature of the being itself, and human is its organ. In this case the main object of care is the person's aspiration to step in the "passage of being", enrooted in being itself, and to shape himself as an organ of being, through which being reveals itself to human in its unconcealed form. Revelation of the concealed is the ontological sense of care, while the entire human becomes an organ of care, which cannot be restricted or reduced to any ontical or empirical examples.

It is worthwhile remarking that we are speaking of "care" as the root part of the ontological presence, not as "self-care". The subjective prefix appeared in culture much later. It all began with the pre-ontological image of the mythological deity named Cura, then it entered the flesh of matter as the primary element of water or air, and remained there as the being of a human directed to itself. Then the reflective "self" prefix began to dominate in the scope studied by researchers, and various authors got involved in studying this prefix more than care itself.

Leaping ahead, let us remark that the majority of works by various researchers are dedicated not to the phenomenon of care as a special practice, but its prefix, i.e. to the meaning of caring of one's self, to who the subject of such care is, what the object of care is about, what the practice of care is like etc. all the way to such applied aspects as technologies and methods of care. Thus, in many 
of the researches the person cares about himself, not the care as such, not being as presence.

However, let us point at some opacity of the topic in M. Heidegger's work. The subject matter is the second most significant work by M. Heidegger after "Being and Time", which is "Contributions to philosophy (from Enowning)" (Heidegger, 2009). This work was published not so long ago and the first comments were given by Bibikhin, V.V. (Bibikhin, 2009).

In this work, Heidegger continues speaking of care ontologically: "Seeker, guardian, and caretaker: this is what care means as the basic trait of Dasein. Man's determination is gathered in these names..." (Heidegger, 2009: 67). If there is any leap, any shift in this work by M. Heidegger, then it is directed towards the concept of Event, which practically continues the motive of purely ontological character of care as a way of being for a human, since the human's care of being is what makes its being eventful and ontologically consistent (see above in our Section 1).

As M. Heidegger suggests, a person cares of himself as of existence, when he performs the act of opening up to the unconcealed (concealed) being, roots into the unconcealed and therefore becomes a measure for the existence of being himself (Heidegger, 2007: 121). Human is a measure of existence as much as he opens up to the existence and as much existence as the unconcealed opens up to him. This action of opening oneself up to the existence is the ontologically enrooted form of caring of oneself as of a human.

The ontological tope problems also encompass the issue connected with distinguishing between "self-cognition" ( $\gamma \nu \tilde{\text { }} \vartheta$ í

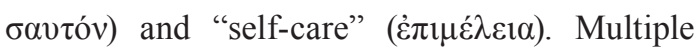
authors, even those familiar with the cultural etymons of the care phenomenon, practically equal the notions of care and self-knowledge. At the same time, the difference between knowledge of one's self and care of one's self was established in literature long ago. This difference is clear on the cultural material we obtain from comparing the figures of Oedipus and Socrates (see the same in our article (Smirnov, 2015: 642-657).

In the commonly known tragedy, Oedipus found himself in the situation where he gradually discovered the horrible truth of himself. When sighted, the hero was not aware of what he was doing. Having discovered the secret, he decided to blind himself ${ }^{2}$. The collision is in the fact that the hero discovers what had been meant to be. The destiny of the hero is to discover the things that are already known, but not to himself but to the gods. This is what the phenomenon of knowledge is about: the person discovers something that already exists in the world; and he, the subject of cognition, armed with cognition tools, opens the world up like a can opener. Just bang - and the world is known. It is discovered, open, conquered. In its turn, knowledge of the world becomes a conquering tool, a weapon. This is what the European science history is based on. The scientist himself resembles the mythological hero: he also discovers secrets of the world. Sacrificing himself, worshipping science, at the alter of the truth he finally gets the access.

But phenomenon of care is more sophisticated. Care of the self is not about discovering the world; it is about selftransformation. The latter is the condition of the access to the truth. Unlike Oedipus, Socrates, calling Alcibiades to take care of his soul, instructed him what and how he had to do: "exercise yourself first, my wonderful friend" (Alcibiades I, 132b)! Knowledge of both the world and one's self is a scientific experiment, while care is more similar to a spiritual exercise, P. Hadot remarks. In Alcibiades I, Socrates states that "we could perhaps recognize what care of ourselves is, but in ignorance of this we never would" (Alcibiades I, 129a). Taking care 
of himself, the person recognizes the care as

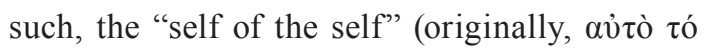

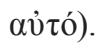

P. Hadot and M. Foucault, who returned the care phenomenon to European intellectuals, wrote a lot about it in thorough details ${ }^{3}$. Following them, almost all researchers study the phenomenon of Foucault himself, speaking of care in his words and seeing the phenomenon of care through his eyes, introducing the difference between the notions of "metanoia", or transformation ( $\mu \varepsilon \tau \dot{\alpha} v o 1 \alpha$ ), and return to the beginning, the origin ( $\dot{\varepsilon} \pi 1 \sigma \tau \rho \circ \phi \eta ́)$.

Based on the lectures by M. Foucault, A.V. Akhutin demonstrates the aspect of distinguishing between cognition and transformation, and demonstrates that the French philosopher used his own meanings and connotations of the notions of subject, cognition, and hermeneutics, that cannot be applied to the Classical material in their pure sense (Akhutin, 2009). Obviously, in the Classical tradition there could be no subject or hermeneutics in the New European understanding of these words. The Classics had separated cognition

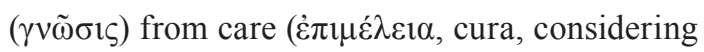
various derivates and correlations with other concepts, such as $\pi \alpha 1 \delta \varepsilon^{i} \alpha$ etc). The work with cultural etymons was shown in a more accurate and precise way in the mentioned works by V.K. Pichugina, M.A. Poliakova and others. However, it is time for us to step to the next tope, which is the discourse.

\section{Tope two: discourse of care}

It should be said that "care" and "care of the self" has not yet been fitted into any categorial paradigm of philosophic, psychologic and pedagogic sciences. "Care" is not even mentioned in Russian philosophic dictionaries and encyclopaedias as a separate category. "Care" can be found in the dictionary by V. Dal, in the etymologic dictionary of M. Vasmer, in the explanatory dictionary by S.I. Ozhegov, but only because this word naturally belongs to Russian language.

By the way, the etymology of the word hints on the abovementioned context of the ontological tope: care of dictionaries is described as a special work one is engaged in continuously and for a long time, restlessly; this is something that festers and devours him. This care is always with you, goes along with your life. It cannot be taken apart from your daily routine ${ }^{4}$. At the same time, the natural language dictionaries point out at the context of external care: care as custody and attendance of someone (another person, or a garden, flowers, paddocks, forest, a house, a business etc.). In this case the context is loaded with meanings associated with burden, need, anxiety, that do not make a man happier or, more likely, even vice versa. The idyllic happy life lies on the opposite of care, as a peaceful, trouble-free existence. The context of care as worries and chores one is constantly engaged in, busy day and night, dominates in our natural language. Care does not mean worries only. It is hard work, that requires labour, effort, constant attention. V.I. Dal also points out the figure of a "carer" in songs and wedding ceremonies; that is a guardian, a labourer, a protector, a breadwinner (Dal', 2007: 502).

As for categorial studies, the situation grows even more complicated. The first difficulty is the absence of a dictionary of anthropology or philosophy of man in our Russian philosophy and science. We have a plenty of dictionaries and encyclopaedias in linguistics, pedagogy, literature, theatre, philosophy, medicine etc. But there is no analytical dictionary of anthropology. It has not been compiled, developed or published by the scientific community (see also Smirnov, 2015). This is why the community has not yet developed an anthropological categorial 
discourse as such and has not built an approved terminological basis of anthropological concepts and categories.

The second difficulty is the actual absence of care as a category in Russian philosophic dictionaries ${ }^{5}$. However, they include the category of "education", inside which we could outline the context of self-education and, indirectly, the context of care, but not more than that.

For this reason, the discourse tope remains the most important one in the topic of care, since the opacity and simultaneous mottle of our care talks will always affect our understanding of the care phenomenon.

For instance, V.K. Pichugina defines the phenomenon of self-care as follows: "anthropologic discourse of "self-care" is a verbal and cogitative space objectivizing the "self-care" phenomenon, pre-determining the pedagogical mindsets and mechanisms for the implementation of adult education routes reflected in the conceptual pattern, described in the corpus of ancient pedagogic texts" (Pichugina, 2013a: 8). And only inside this anthropologic discourse, the "self-care" is defined as a "notion, generalizing the ideas of higher education and self-education in the ancient thesaurus, characterizing the interaction between the mentor and his student in the wide space of life" (Pichugina, 2013a: 8).

M.A. Poliakova carried out a thorough analysis of the connection between the concepts and notions of the Ancient Greek $\pi \alpha 1 \delta \varepsilon i ́ \alpha$, Latin humanitas and German Bildung, to track the whole history of the development of care concept from the ancient roots to the ideas of German thinkers and to the reception of the category by contemporary Italian authors working on revival of the cultural etymons with regard to the works by M. Heidegger and M. Foucault (Poliakova, 2015). M.A. Poliakova also remarks, that understanding $\pi \alpha 1 \delta \varepsilon i ́ \alpha$ as forming a man in the image and likeness of God had been maintained by European intellectual tradition for a long time. The rich and ontologically enrooted origin of self-care, are of the self (cura sui) is revived in the works by such contemporary Italian authors as F. Cambi, V. Boffo, S. Camilleri, L. Mortari and others ${ }^{6}$. German concept of Bildung had been long adhering to the rich context of education as search for the image of God in a man and reestablishment of connection to God "who lives inside of him" (Poliakova, 2015: 84). It was especially distinctive in the religious and mystic traditions (M. Eckhart). Italian philosopher M. Gennari quotes the key point from the tractate of M. Eckhart: "A human soul is a field where God sowed his image" (Poliakova, 2015: 84). The sowed image of God always remains in the scope of activity of the man walking across the field, like a living spring? ${ }^{7}$ This moment is critical, for it proves that the Image of God is not somewhere far away from man, in some ontologically alien space, beyond the horizon of the human habitat; it is always here, within reach, inside, within the scope of human activity. But the latter has to work hard to cultivate this image inside himself, to (re)create it.

Along with that, agreeing with the Italian authors, M.A. Poliakova points out that today we witness an inclination to reduction, narrowing of the Bildung concept to a teaching technique in the categories of instruments, practical exercises (Poliakova, 2015: 91). At that the authors, studying the rich cultural tradition of education (Bildung, paideia) in gage of care, relate this activity to the purely historical and philosophic research of tradition, remarking that the modernity does not need such a rich root and high horizon. To react to the reduction challenge, M.A. Poliakova writes, our Italian colleagues try to bring the lost meanings back and even include their works on the self-care concept history in the Classical and New European traditions into advanced training programmes for teachers (Poliakova, 2015: 90). 


\section{Tope three: object of care}

From the point of view of its object, what is the anthropological practice of care about? Following M. Heidegger, care is an ontologically enrooted need of a man to appear existing, developing inside existence as the unconcealed. Due to this need, the human becomes himself as a human being, opening up to the concealed origin, and the origin opens up to him, turning unconcealed. In this situation, care means continuous work of thought and act, connected with such experience of opening, unlocking. Here various practices based on the principle of unlocking may be used.

If we adhere to P. Hadot, care acts as a spiritual exercise performed at least in two formats: the epistrophe exercise targeted at return to the origin, and an exercise as metanoia, aimed at transformation of the person (Hadot, 2005: 199-200). And though both of these are exercises, they assume opening up to the symbolic horizon, the cosmos. For P. Hadot, any philosophic practice (if it is philosophic) may be interpreted as such. As he suggests, such philosophic practice is typical both of antiquity and philosophy as a whole, including R. Descartes and I. Kant.

However, listing the practices, quoting P. Hadot and other researchers after him, does not create a context of care. Reading, meditation, work on attention, listening, remembering, inspection of soul etc., regarded by P. Hadot, do not create the experience of care by themselves; they need to be done in a certain mode, against the horizon of the Good, the thought of which keeps the subject within the context of care (Hadot, 2005: 23-33).

M. Foucault introduced a framework of self-care practices on the basis of several ancient authors (primarily, Roman stoics). He pointed out the following aspects of care:
- epimeleia as a general mindset, way of behaviour, mindset in relation to one's own self, the others, the world;

- epimeleia as a special focus of attention on something, a certain optic of vision, the way of seeing described as a transfer of attention from the exterior to the interior, into one's own self;

- epimeleia as a certain action, a practice, used to carry out the act of care leading to some transformation of one's own self; epimeleia as a set of practices and exercises (i.e. a certain ascetic practice performed through such techniques and exercises) (Foucault, 2007: 23).

In other words, Foucault believes, reconstructing the ancient stoics' experience, that care of one's self is a certain practice of spirituality, assuming some practice of transformation that opens the "access to the truth" for the subject. Without the transformation, the subject cannot achieve the access to the truth: "It postulates that for the subject to have right of access to the truth he must be changed, transformed, shifted, and become, to some extent and up to a certain point, other than himself ... For as he is, the subject is not capable of truth... there can be no truth without a conversion or a transformation of the subject..." (Foucault, 2007: 28).

And why would the subject need the access to the truth? "The truth enlightens the subject; the truth gives beatitude to the subject; the truth gives the subject tranquillity of the soul... there is something that fulfils the subject himself, that fulfils or transfigures his very being" (Foucault, 2007: 29).

These quotes encompass the whole range of problems of this talk. Let us formulate them over again in the form of questions.

Do the postulates of Foucault mean that the subject takes care of oneself for the desire to reach tranquillity of the soul, to fulfil his being, to achieve his ultimate dreams and aspirations? Does it mean that care of the self is not an autotelic 
act? Does it mean that it is not liability to God, but tranquillity that bothers the man? Does he need to understand what "self-fulfilment" means? When, where and how does it happen? Who can decide that the subject has fulfilled its aspirations and has reached tranquillity?

What does understanding of the transformation measure mean? Where is this measure? Who, how, which way registers this transformation measure used to determine that some transformation has happened and the subject has achieved the access to the truth?

And what does self-transformation mean? What is the object of such transformations? And speaking of the "self", who are we speaking about ${ }^{8}$ ?

Secondly, this reconstruction was not the ultimate target. He was mostly interested in the modern situation of man.

Thirdly, at the end of the lectures he confessed that for the Ancient Greeks, real transformation (metanoia, the transformation of mind) could not be achieved. It was explained with the limit of their cultural horizon, for the Ancient Greeks did not know the meaning of personality, the concept and practice of which developed later, in Christian culture. It is the phenomenon of personality that reveals the fact, the precedent of transformation?.

But this is not what it is about. This far the subject matter is care as a concept, i.e. its object, subject, and practice. What is the object of such practice of self-care? What makes a subject take up this practice of care?

Let us return to the first questions we asked ourselves on the basis of the Foucault quotation. If any subject carries out the practice of self-care, striving for tranquillity of the soul that is defined as a feeling of having complete his personal aspirations, then we have no answer. Because there is no one, including the care practice bearer himself, who can determine the limit of such aspirations.
Then, it is the discourse that needs to be changed. Let us elaborate on the concept of it, answering the basic question, what the care of the self means.

Let us assign the objects of care to the vectors: care as adhering to an external regulation and care as an instruction and spiritual exercise coming from inside.

The moral and pedagogic basis of care appears immediately when an external rule, or regulation, is given: do this, and do it this way.

And then the external regulation looks like a rule to be followed. Here care is limited to a set of rules, or commandments. These rules cover various spheres and fields of activities.

Sphere of cognition. Act according to the "rules for mind work", follow the regulations and rational action rules and you will recognize the object, i.e. you will actually possess it. $\mathrm{R}$. Descartes formulated these rules, introducing a rational regulation for any cognition. To perform the cognition process in the right way, anyone needs to follow it ${ }^{10}$. Isn't it a way of care? If you do not follow the rules, you do not get the object, and you do not get the sought knowledge. But the thing is that to adhere to the cognition rules coming from outside (mind discipline), you need to do a certain work to adjust to the rules, to make an effort that will lead to some changes in your personal structure. Therefore, an external regulation, implied to you and accepted by you as a rule for action and behaviour, becomes a part of your internal personal structure.

At all that, it is clear that for Descartes "I as a thinking thing" is obvious and does not need to be proved. Indeed, for it is an unchangeable thing. For Descartes, having I as a "thinking thing" is an unchangeable, an untransformable pillar, that does not even need any transformations, just because that is the reason that makes me exist. It shall not be changed. It sets the frame and stability to me and my existence ${ }^{11}$. 
But how strange it is! Had Descartes ever experienced any transformation? In his "Meditations", he described an almost magic act of metamorphosis. Miraculously, the hero gets knowledge. Suddenly his eyes open and he sees something. He sees the light. He realizes he had been thinking wrong. But such a metamorphosis is not a result of a purposeful previous work/care.

Sphere of moral. Act according the moral regulations of the society, or you will be reproached. Be kind, honest, and decent, be good in thoughts and deeds etc. But there are some more difficult regulations: think of thy soul. Look after your clothes when they're spick and span, and after your honour when you're a young man. And there are some more difficult ones. "So in everything, do to others what you would have them do to you, for this sums up the Law and the Prophets" (Mathew, 7:12). But such a regulation cannot be fulfilled right away. It requires discipline, i.e. a correctly developed behaviour that also influences one's internal structure.

Sphere of education. Follow an academic discipline, its logic and essence, follow the instructions of your teacher and you will become as knowledgeable as himself. But here the same law of instruction comes into force: being an external academic discipline, becoming discipline as an internal structure of regulationabiding behaviour, becomes a part of one's own personal organization. By the way, Foucault himself also remarked the principle of care of the self in pedagogy, driving it into the internal sphere, or psychogogy: a teacher shall care of the care, to make his student take care of himself (care of care) (Foucault, 2007: 75).

Sphere of health and medicine. Actually, the principle of care begins from such simple things as care of one's physical health. Physical exercise is accessible to anyone. Spiritual exercise is harder to do, and it is treated differently, though the principle is the same. Taking care of your body, improving it, engaging yourself in this bodily athleticism, you develop your order of life and schedule of the day, because physical exercise requires time, effort; you need to develop some power of will to do running or gymnastics. But here the measure of changes applies again: a runner may ignore a disabled person or a fallen child, pretending not to have seen them. Flexible body and developed muscles do not mean spiritual fitness.

Similarly, we may consider some other spheres (for example, professions as regulations for professional activity). But it has become clear that consideration of the self-care principle as an external regulation and instruction (do this and that) sooner or later takes the subject of such instruction to the border, beyond which he begins to change himself. This border, the point of transition from the external to the internal change, is regulated by himself as reflective adjustment, while adherence to external commandments may or may not lead to spiritual change. Observation of such adherence does not reveal the spiritual organon built inside.

Looking ahead, let us say that it is the reflectivity that seems to be the "subject", or that thing in the subject that actually needs care. But let's talk about it later.

So, we arrive at the notion of internal regulation, i.e. some spiritual order, the organon of the personality that is developed in the selfcare practice. From care as external instruction, we step forward to care as an internal spiritual exercise and practice, in the process of which soul organization is developed. That is when we may speak of some changes in the person.

This is what Foucault meant, saying that this is what care, or epimeleia, means: changing one's own self as a condition of access to the truth. Apply some effort to yourself, change yourself and you will discover something that you cannot achieve through any external regulation. That is 
when the care of the self becomes the ascesis, the practice of abstinence and self-transformation.

In this case, we may speak of care of the self as a basic anthropological practice, for it implies development of what makes a man a man, i.e. a creature capable of metamorphosis, of a second birth. It is care of the self that launches the mechanism of opening oneself up to the other and transformation of the self.

But to do it, we need to introduce some framework, some benchmarks that would outline the limits and borderlines of self-care as a concept and a practice.

Benchmark one: care of the self as epistrophe

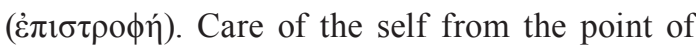
view of seeking support, understanding of one's self, his place in the world, his origins. Who am I? Why am I? These first questions of the meaning of life are asked by any living man in different formats, genres and with different intensity, especially in the periods of crisis and identity loss (problem seeking and disorientation). This benchmark means the thing the boy did for Plato. The revival of the origin, anamnesis, was later referred to as epistrophe.

Benchmark two: care of the self as agon (á⿱㇒⿻丷木). Care as fitting and equipping the self with external protection.

Comprehending his own self, a person thinks of external protection, of creating some line of defence for himself. It is needed just because an individual does not have any other support and power for anything else. Coming across some aggression, all he does is defence. A human being is not born as a subject of care by definition. As an individual, he has no developed new functional organs of internal care. Later, defence moves into the model of behaviour.

Above we remarked the care of one's self in the sense of care of one's body and health. There is a superobjective underlying care itself. For what sake is the care of one's self needed?
For example, the subject of care carries out the practice to be wealthy and fit in the sense of psychological, physical outfit. An ancient wrestler, runner, athlete was engaged in caring of himself, exercising javelin throwing, running, or wrestling. There were some competitions among poets, philosophers and tragedy writers during Dionysia. Even life itself was perceived as an endless agon, contest, battle. The purpose of agonistics was the victory. A competing mortal could dare the gods themselves, as it was frequently described in various myths. An agon, a battle becomes a model of behaviour. And then the criterion for completeness of such agon-care is the outfit of the subject. He needs to be fit in order to win, to overcome all difficulties, to go all the way and defeat his enemy, his competitor.

Agon-care as such becomes an independent branch of care practices that have survived to our days. A hero, an Olympic athlete, a knight of body and mind, fit for battle and war, for the contest for the victory becomes the subject of agon-care. By the way, the asceticism motive is also present in the training of body and mind to go through the sufferings of battle against a strong rival.

However, the asceticism has its limits. In agon practices, an athlete, fitting himself and training his body and will, makes himself stronger and does not deny himself, while the ultimate care of one's self means rejection of the self, getting over of the self, denial of one's individuality and inferiority. Though athleticism arms and fits, strengthens the individuality of a person.

Care as spiritual athleticism, training of soul and body, exercise of psychological features is based on the same logic. The notion of "sensual athleticism" was once introduced by A. Artaud in his project "The Theatre of Cruelty" (Artaud, 2000). To take part in it, the actor needed to be as well-trained as an athlete before competitions. But this care is not a goal in and of itself. It is an 
essential condition to create a new, conventional reality on stage using your physical and spiritual organism. The actor's fitting his role in an ecstatic practice and his return back to ordinary life does not require compulsory transformation of the actor's personality. For an actor, all these are the techniques of playing, an actor's way of being.

Benchmark three: care of the self as

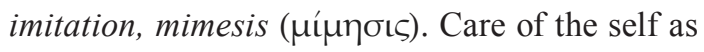
transformation and imitation of the exterior. To protect himself more thoroughly and accurately, the subject of care develops his mechanisms and behaviour plans for such mimesis, which enables him not only to survive, but also to undergo some radical changes and assimilate with others so much, that no one would recognize him.

So, we are gradually approaching the topic of imitation, the topic of care of the self as mimesis. In his "Poetics", Aristotle described the phenomenon of art in the categories of mimesis. A person explores the world by imitating it, producing things similar to the world. Through this resemblance and imitation he gets to know the world. Copying another person, the person changes himself. This was the origin of theatre as mimesis, play of an actor wearing a mask

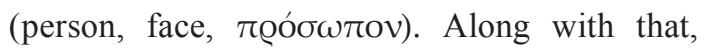
such mimesis to the world does not require selfdenial, just like agonistics do not require selfdenial and transformation. In mimesis practices, a person changes his clothes, or even appearance, psychological individuality, specialness. He can even change his body, his gender, or social identity. But going through all these changes, he is moving towards himself, not away from himself. This sort of care is indulgence to the self. Such practice of changes implies acting according to your own self, towards yourself. In the ultimate form, this care is caress, tenderness, enveloping and soothing you. You learn imitation of the world and other living beings, you learn how to walk and move, speak, sing like someone else.
You can do it this way or that way. You are almost the one you imitate. But it is always "almost". "As though" you are someone else, but it is not you. It is the person you imitate. You pretend, it is not real, it is a make-believe. You are not an animal, or a train, or a car, or some wind, even if you act like a car or like wind. Through these constant practices of imitation you surely change, but it is mimicry, like an animal changing its colours. Such individual capacity of mimicking and pretending is the specialness, individuality of the subject of pretending. But this sort of care has its limits and boundaries. This care is similar to the agon-care. But an agonist outfits to win, while the pretender masters various techniques to imitate the object of mimesis more and more accurately. He is striving to blend with the object of mimesis, to dissolve in it, so that an observer does not notice any difference.

Benchmark four: care as cogito. Care as thinking understood in the categories of cogito. As an act of thought driving the author of thought to the limit of cognition. Care as a reflective act outlining the borderline of the act of thought itself.

Benchmark five: care of the self as transformation, metamorphosis of the personality.

Only after the first abovementioned practices, the subject develops the experience of care and is considered to be ready for internal transformation. It cannot be forced on him as a repression. He may take up this practice only through the maturity of soul and acceptance of the need for care, as care of overcoming his own self, mundane and inferior.

Gradually the practice of changes reaches its limit, after which the subject of changes has done so much and has changed his initial individual nature so much that it just disappeared. Ultimately, care of the self, in this sense, means refusal of the self, refusal of one's old and sinful essence. Then, care of the self turns 
into autopoesis ( $\alpha \dot{\tau} \tau 0-\pi 0 \iota \eta \sigma \iota \varsigma)$, which means practice of transformation of the self by the self, by means of doing spiritual exercise and training for the sake of transformation and discovery of Another, ontologically different world. Basically, this care within the epimeleia limits is the practice of transformation, metamorphosis of the individual, his radical overcoming himself and reaching the level of personality, i.e. the product, the poem, the cultural product. The subject of care composes himself, re-writes himself all over again, improving his product, which is personality ${ }^{12}$.

In Section I above we referred to the experience of classification of practices in the history of European thought, described by a well-known author, translator of M. Foucault, A.G. Pogoniaylo. He outlined four types of the subject conversion (Pogoniaylo, 2007). Those are the practices of epistrophe, agon, metanoia, and cogito. Obviously, we have a lot in common.

Type one: experience as a memory and reconstruction of the initial source. This is

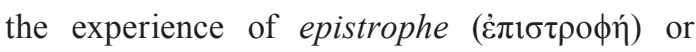
anamnesis ( $\dot{\alpha} v \alpha \dot{\alpha} \mu v \varepsilon \sigma 1 \varsigma)$. This experience implies the practice aimed at reconstruction of the lost connections, finding the lost support. This experience is similar to recalling a once forgotten beginning. Conventionally, it may be referred to as Plato's model of conversion experience.

Type two: experience as exercise, implying strengthening the subject in his abilities and his outfit. It means strengthening of the self, body and spirit, continuous exercises. This is agon experience ( $\dot{\alpha} \gamma \omega \dot{v})$. This type is more characteristic for the Hellenistic model of care experience and first of all, of the stoic experience.

Type three: experience of conversion, transformation, "change of mind" (metanoia, $\mu \varepsilon \tau \dot{\alpha}$ vola). This is the experience of transformation care, implying the denial of the old self, asceticism as an exercise for suppress the mundane and sinful self for the sake of transformation and building a new organon, the organon of personality. This experience is typical of the Christian model of the care of the self.

Types three and four may be considered to be the experience of asceticism. One of them implies the test of the self for the strengthening of subjectivity and physicality, while the other means the test of the self for mortification of the self and the flesh, overcoming the old self and transformation, re-creation of the self through calling for the Other.

Type four: experience as a pure thought based on cogito principle. This experience does not imply any asceticism, denial or the self or separation from the self. It does not include any drama of death and resurrection. It is more similar to the experience of cognition on the basis of certain rules, to the discipline of mind, experience of reflection, driving the self and cognition experience to the border of experience for the cognitive shift, transcendence of the self to the border and return back to the self. Here the experience of conversion implies a move from the self to the self, like swings (back and forth), shifting to the border of one's own experience and returning to the changed self that has recognized something.

This type is characteristic for the Modern time; developed on the basis of experience of R. Descartes and I Kant, it underlies modern type of thinking.

It should be noted, that M. Foucault basically interpreted the Roman stoics in the language of the conversion type four, in the categories of the Modern-type thinking, in the language of R. Descartes. Implicitly, M. Foucault used the cognitive model language, discussing agonistics and asceticism of the stoics and Christians.

By the way, S.S. Khoruzhiy notices that M. Foucault was wrong in his reconstruction of the practices of the self; he claimed that the 
Hellenistic model of the practices was a more adequate model for understanding care of the self, while the later Christian model of self-rejection was a step backwards (Foucault, 2007: 281285). For Foucault, the experience of monastery asceticism meant separation from the practices of the self. As Khoruzhiy suggests, the ancient practices of the self lacked the basic element, which is the ontological measure, opening up to the ontologically Other; there was no practice of unlocking that was later developed in the Christian monastery ascesis (Khoruzhiy, 1998).

In any case, if we happen to step aside from the topic of reconstruction of the ancient and Christian practices, care of the self really begins with the radical problematization of the self, from the "selfexclusion" principle formulated by M.M. Bakhtin: "The great meaning of activeness, the reposed Christ, in the sacrament, in the distribution of his blood and flesh, is alive and acting in the world of events through the permanent death he experience, as the one reposed from the world; it is his unexistence in the world that keeps us alive and communed to him, supported. The world Christ has left will never be the same world where he has never been; it is principally different. This world, where the happening of life and death of Christ in their fact and sense, is principally undefinable in any theoretical categories, or categories of historic cognition, or aesthetic intuition" (Bakhtin, 2003: 19).

This principle may be demonstrated on the example of a deed, to be its witness and its judge. That is what Bakhtin described as a manifest: life may be recognized in a certain responsibility, "as an event, not as a given being. Separated from responsibility, life may not have its philosophy: it is principally accidental and impossible to enroot" (Bakhtin, 2003: 51). The sense of the ontological crack was found in the "abyss that appeared between the motive of a deed and its product. As a consequence, the product separated from its ontological roots died away" (Bakhtin, 2003: 50).

This is the reason why a person has no alibi in being; he experiences some ontological "architectonic obligation" to actualize his only place in the only event-being, as an axiological opposition of I and the other", and the meaning of such opposition is "the absolute self-exclusion" (Bakhtin, 2003: 68).

Thus, care of the self is an ontological duty of the person, and for this reason it may not be limited to any theoretical act of cognition, or to adhering to some external moral instruction, or to the wilful effort of an athlete, or to the psychotechnical exercise-action, or the theatrical mimesis of the actor.

\section{Tope four: the subject of care}

So, we discovered that the object of care may be different. But then, who is the one who carries out the care? What is his subjectivity, individuality, personality? Who is the bearer of the care practice?

As it has been remarked above, based on the ancient practices of the self, Foucault formulated this subjectivity as reflectivity, reflective recurrence (Foucault, 2007: 53-54). Practice of the self implies application to the object of care. And if the New European understanding of the cognition subject may not be applied to the ancient practices of the self, some practice of reflectivity to oneself as a practice of care in the style of Roman stoics seems quite applicable.

Therefore, the subject matter is not the subject as a ready independent source of thought as in cogito principle of Descartes, it is the personal reflection that is absent in the natural you; you have to develop and cultivate it. Then, starting from Socrates, the subjectivity of care is understood as a special activeness of care of god in one's self, in the soul, in the moral organization of the human internal structure. 
Later, in Christian praying practices of care, we find the fixation of limitedness, transition and activeness of the borderline adjustment with the ontologically Other, ultimately, with God. It is through the care of the self that the special border, contour of the cultural body, the body of personality, is formed.

In any case, subject and subjectivity of care are understood as a special activeness on the border between one's self and the other. It is the reflective recurrence, continuous being on the border between the self and the other, the continuous experience of crossing the border and, therefore, comprehension of this border and the borderness of the experience, that creates the organon of care, through which such care is performed.

\section{Tope five: care as practice}

The most difficult, the almost mystical question about the experience of the practice of the self is the practice of care as it is. What does the person do that can be understood as such practice? What does it practically mean, not in the narrow mundane sense, but in the category of spirituality? Basically, that is what Foucault was mostly interested in: description of the practices of the self as practices of spirituality.

Strictly, the cultural etymon itself implies that practice is not limited to action. Practice is a deed you do with knowledge, special attention, responsibility, and love. Being practical ( being responsible, in charge of some action, which actually means care.

Then, as it has already been said above, practice of the self as a sort of care means practice of one's transformation of his own self, of his individual, old structure, the structure of an "old", mortal person, and building a personal structure, a cultural organon on top of it.

In different researchers such practice is referred to in different ways: spiritual exercise, spiritual practice, cultural practice, anthropological practice.

Often such notions seem to be synonymic. But they differ from each other, and not only in the emphasis.

P. Hadot understands spiritual exercise as "wilful personal practice aimed at the transformation of an individual, selftransformation" (Hadot, 2005: 140). P. Hadot principally understood ancient philosophy as a practice of spiritual exercise that can be found not only in the works of stoics. He understood any philosophic speech as a spiritual exercise. In this exercise he primarily emphasized selftransformation of the person carried out with the effort of will. At that, he understood such exercise as not an exercise for the sake of exercise, but as an "effort on self-revelation of the biased and personal points of view connected with body and feelings, to ascend to the universal regulatory point of view and to submit oneself to the requirements of Logos in the norm of the Good" (Hadot, 2005: 42).

For P. Hadot, all philosophy of the ancient time was such a practice, a spiritual exercise. It was targeted not at the building of speculative concepts and systems, not at informing, but at forming. Ancient philosophers exercised their thoughts and through this action committed some self-transformation experience. Hadot mentions a lot of such examples, without drawing a principle borderline between Socrates, Plato, Marcus Aurelius or late Christian saints, such as Ignacio de Loyola.

Along with that, if we introduce principal differences not only between the use of words, but also between the concepts and essence of practices of care of the self, then, for example, S.S. Khoruzhiy separates spiritual exercise from spiritual practice. He believes that as a transformation practice, a spiritual practice is different for having an underlying "ontological 
Table 1

\begin{tabular}{|c|c|c|c|}
\hline $\begin{array}{l}\text { Anthropological } \\
\text { practice of care }\end{array}$ & $\begin{array}{c}\text { Identity of the practice } \\
\text { subject }\end{array}$ & Essence of work/care & Telos of work/care \\
\hline Epistrophe & $\begin{array}{l}\text { Contemplating } \\
\text { researcher }\end{array}$ & Memory & $\begin{array}{l}\text { Recreation, } \\
\text { establishment of } \\
\text { supports and elements }\end{array}$ \\
\hline Agon & Athlete & $\begin{array}{l}\text { Arming, equipping, } \\
\text { outfitting the self }\end{array}$ & Victory in the battle \\
\hline Mimesis & Actor & $\begin{array}{l}\text { Imitation, adjustment, } \\
\text { creation of a copy, likeness }\end{array}$ & $\begin{array}{l}\text { Blending in the copy } \\
\text { with its original }\end{array}$ \\
\hline Cogito & Thinker & $\begin{array}{l}\text { Reflective establishment of } \\
\text { the borders of thinking }\end{array}$ & The act of thought \\
\hline Autopoiesis & Philosopher, poet & $\begin{array}{l}\text { Transformation and } \\
\text { reflective transitions of the } \\
\text { ontological border of the I } \\
\text { and the other }\end{array}$ & $\begin{array}{l}\text { Condition in the event- } \\
\text { being }\end{array}$ \\
\hline
\end{tabular}

drive", and implying a "conscious active action, setting an ontologically relevant goal (i.e. touching on the fundamental predicates of human existence, nature and way of being of a person" (Khoruzhiy, 2000: 382).

In this regard, the comprehended spiritual practice is the sought anthropological practice, implying a person's action for self-transformation and building an organon of person on the borderline with the ontologically Other.

To finish our talk, let us present the table (Table 1) demonstrating the differences between the anthropological practices of the care of the self in their objects, essences, subjects, and super objectives with regard to the above classification experience and building the care topic.

Obviously, the titles refer to the identity of subject, not to his profession. It should be also noted that the differences are conventional and do not imply any objective or material establishment of this or that practice. The practices differ not only physically and objectively, but in their essence and purpose. In this regard, an actor's work of the self may be agon, or mimesis, or even end up with transformation, just like a philosophic speech may be dedicated to agon, may be a theatrical action, or may become an act of transformation.

1 The discovery of this mythological story is significant by itself. M. Heidegger came across the story in one of the articles by a poorly known author C. Burdach "Faust and care". The latter pointed out that he adopted the story from Goethe, who had used it for his Faust. But he also borrowed the story from Herder. The latter found the fable in a book by a Roman writer (Heidegger, 1997: 197, remark 1). Literature knows plenty of travelling adventure stories. This is why they keep travelling: they touch on the archetypical and existential features of human existence.

2 If what we mean is the aesthetic change made by Sophocles. The whole tragedy of Sophocles is based on the game of blindness and sight. That is what S.S. Averintsev wrote about (Averintsev, 972). Previously, the final of ancient mythological stories looked less theatrically and aesthetically: having discovered the secret, the hero of the ancient myth castrated himself. The blindness of Oedipus may be considered to be a later aesthetic change. (Graves, 1992: 284).

3 However, that was the shortened version of the return, in the form of "self-practices", but without being, for which P. Hadot had been criticizing M. Foucault, reproaching him of "dandyism" (Hadot, 2005: 210). The return finally happened in the version of "Foucault without Heidegger".

4 The Russian word care (zabota) may be related to the root zob, zobati "to eat (grain)", "to dab", "to devour", because caring about something eats a person, devours him from inside (Vasmer, 2004: 70-71).

5 Let us remark that in the European tradition the situation is a little better, for the Latin cura had naturally entered the concept list of the European scientific discourse and is now present in the modern thesauruses (see Pichugina, 2014, 2013a, 2014b; Poliakova, 2015).

6 It should be noted that Italian authors pay more attention to the ontological topic of care, connecting it both to the works by M. Heidegger and rich mystic and religious traditions. M.A. Poliakova also writes about it. There was a great series 
of translations of the Italian authors mentioned and not mentioned above, published in Russian scientific publications (Graves, 1992; Kambi, 2015; Camilleri, 2015; Mortari, 2015).

7 One of the archetypical cultural images of care is a sower, pushing the plough across the field, copying the divine cultivation and bringing up the seed of peace, likening his education and care of the world to the cultivation of the image of God sowed inside himself. This image was also reflected in the well-known mystic saying formulated as the palindrome: "Sator Arepo tenet opera rotas" ("The farmer Arepo has [as] works wheels [a plough]"). The five words are written in a square symbolizing a demarcated field, across which a sower with a plough is walking, repeating the Primary Action of the God the Demiurge, the Creator (Sator). All words inside the square read the same in both directions.

8 A.V. Akhutin and other researchers suggest that it is not hermeneutics and not the subject that is the subject matter of Foucault's lectures (Akhutin, 2009). It looks right. Foucault himself spoke of the death of the subject, of the ultimate experience of "desubjectivization" of the subject, of the experience letting the subject tear himself out from his own self. But it does not make it easier. Then what or who is the subject matter? Yes, it is not hermeneutics; it is the care of one's self. Yes, it is not the subject, but what is it about then?

9 But to be more precise, at the close of his days, in one of the interviews Foucault confessed that the ancient "culture of the self" had played itself into the corner. The practice of the self begins with a live action, but then turns into the moral obligation and finishes as a dogma and a moral doctrine, conversing into its opposite. Having turned into a dogma, care of the self is not such care anymore (Foucault, 2007: 561).

10 It should be mentioned that Foucault intentionally paid attention to the so-called "Cartesian moment" in European culture, after which the person forgot of itself, preferring the strategy of cognition of an object over self-care. Foucault referred to this moment as to "Cartesian", though he had always admitted the conventionality of the term (Foucault, 2007: 30).

11 In this regard, the Nosce te ipsum principle does not mean adhering to the self-care principle. Nosce te ipsum means, discover something concealed from yourself, your secret, your destiny, which under certain conditions will one day come true. This principle, adopted from the culture of the myth, where a hero discovered a secret on his Way, following certain instructions, was later transferred to the culture of scientific recognition. Strangely, the Way mythologem also remains in the purely rational way of action. While a scientist appears to resemble Oedipus, who opened his eyes to realize who he is and what he is actually doing, to realize that before he had been blind and unaware of himself.

12 By the way, speaking of cultural etymons, autopoiesis means an action on cultivation of the real object, not its copy. Autopoiesis is the one who presents the real object, not its copy. I.e., unlike mimesis as imitation, presenting likeness, autopoiesis creates a real object, i.e. the self as it is.

\section{References}

Akhutin, A.V. (2009). Praktika sub'ektivnosti i/ili germenevtika sub'ekta. Kriticheskiy analiz otnosheniia "poznaniia sebia" i "zaboty o sebe" u pozdnego Fuko [Practice of subjectivity and/ or hermeneutics of the subject. Critical analysis of correlation between "cognition of the self" and "care of the self" in the late works by Foucault, In: Chelovek.RU. Gumanitarnyy al'manakh [Human.RU. Humanitarian almanac]. Novosibirsk: Novosibirsk State University of Economics and Administration, No. 5. P. 44-66.

Artaud, A. (2000). Teatr i ego dvoynik [Theatre and his double]. Saint Petersburg: Symposium, 440 p.

Averintsev, S.S. (1972). K istolkovaniiu mifa ob Edipe [To the interpretation of the Oedipus story], In: Antichnost' i sovremennost' [Antiquity and modernity]. Moscow.

Bakhtin, M.M. (2003). Sobranie sochineniy. T. 1. Filosofskaia estetika 1920-kh godov [Collection of works. Volume 1. Philosophic aesthetics of the 1920-s]. Moscow: Russkie slovari Publishing House, Languages of Slavic Cultures.

Bezrogov, V.G. (2015). Obraschenie i preobrazhenie kak zabota o sebe: pedagogicheskaia paradigma khristianskoy kul'tury [Conversion and transformation as care of the self: pedagogical paradigm of Christian culture], In: My vse v zabote postoiannoy... Kontseptsiia zaboty o sebe $v$ istorii pedagogiki i kul'tury [We are so caring all the time... The concept of care of the self in the history of pedagogy and culture]. Proceedings of the International Conference in the memory of philosopher, sociologist, psychologist G.V. Ivanchenko (1965-2009) (Scientific and research institute of the Higher School of Economics, Moscow, September 9-11, 2015). Edited by M.A. Kozlova and V.G. Bezrogov. Part 2: Chto-to vediot nas vglub' samikh sebia... [Something is leading us into the depth of ourselves...] Moscow: Canon+, P. 99-111. 
Bibikhin, V.V. (2009). Haydegger: ot "Bytiia i vremeni] k Beiträge [Heidegger: from "Being and

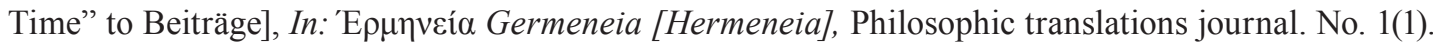
P. 95-118.

Boffo, V. (2015). Prepodavanie kak zabota o sebe [Teaching as care of the self], In: Izvestiia Volgogradskogo gosudarstvennogo pedagogicheskogo universiteta [Newsletter of Volgograd State Pedagogical University]. No. 4(99). P. 10-19.

Camilleri, S. (2015). Ot zaboty "filosofskoy" do zaboty "religioznoy" [From "philosophic" care to "religious" care], In: My vse v zabote postoiannoy... Kontseptsiia zaboty o sebe v istorii pedagogiki $i$ kul'tury [We are so caring all the time... The concept of care of the self in the history of pedagogy and culture]. Proceedings of the International Conference in the memory of philosopher, sociologist, psychologist G.V. Ivanchenko (1965-2009) (Scientific and research institute of the Higher School of Economics, Moscow, September 9-11, 2015). Edited by M.A. Kozlova and V.G. Bezrogov. Part 1: Postoianstvo prebyvaniia s soboiu [Stability of being with the self] Moscow: Canon+, P. 55-82.

Dal', V.I. (2007). Tolkovyy slovar' zhivogo velikorusskogo iazyka [The explanatory dictionary of the living Great Russian language], in 4 volumes. Volume 1. Moscow: OLMA Media Group.

Fedicheva, K.V. (2010). Zabota o sebe: filosofskiy, ontologicheskiy i eticheskiy aspekty [Care of the self: philosophic, ontological, and ethical aspects], In: Vestnik Leningradskogo gosudarstvennogo universiteta [Newsletter of Leningrad State University]. V. 2, No. 3. P. 136-144.

Foucault, M. (2007). Germenevtika sub'ekta: Kurs lektsiy, prochitannykh v Kollezh de Frans v 1981-1982 uchebnom godu [Hermeneutics of the subject: Lectures at the College de France, 19811982]. Translated from French by A.G. Pogoniaylo. Saint Petersburg: Nauka.

Graves, R. (1992). Mify Drevney Gretsii [Myths of Ancient Greece]. Moscow: Progress.

Hadot, P. (2005). Filosofiia kak sposob zhit': Besedy s Zhanni Karlie i Arnol'dom I. Devidsonom [Philosophy as a way of life: Conversations with Jeannie Carlier and Arnold I. Davidson]. Translated from French by V.A. Vorob'iov. Moscow, Saint Petersburg: Stepnoy veter Publishing House, Kolo Publishing House.

Hadot, P. (2005). Dukhovnye uprazhneniia $i$ antichnaia filosofia [Spiritual exercises and ancient philosophy]. Translated from French with contributions from V.A. Vorob'iov. Moscow, Saint Petersburg: Stepnoy veter Publishing House, Kolo Publishing House.

Heidegger, M. (1997). Bytie i vremia [Being and time], translated by V.V. Bibikhin. Moscow: Ad Marginem, $452 \mathrm{p}$.

Heidegger, M. (2007). Nitsshe [Nietzsche], translated from German by A.P. Shurbelev, in 2 volumes. Volume II. Saint Petersburg: Vladimir Dal', P. 118.

Heidegger, M. (2009). Vklady v delo filosofii. Ot sobytiia [Contributions to philosophy. From

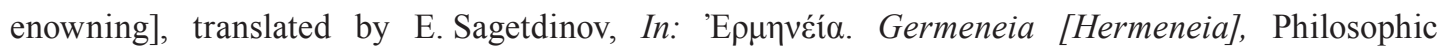
translations journal. No.1 (1), P. 56-94.

Ivanchenko, G.V. (2009). Zabota o sebe. Istoriia i sovremennost' [Care of the self. History and contemporariness]. Moscow: Smysl.

Kambi, F. (2015). Zabota v pedagogike: kriticheskie zamechaniia [Care in pedagogy: critical remarks], In: Izvestiia Volgogradskogo gosudarstvennogo pedagogicheskogo universiteta [Newsletter of Volgograd State Pedagogical University]. No. 4 (99). P. 4-9.

Khoruzhiy, S.S. (2000). O starom i novom [On old and new]. Saint Petersburg, Aleteia. 
Khoruzhiy, S.S. (2010). Fonar' Diogena. Kriticheskaia retrospektiva evropeyskoy antropologii [Diogenes' lantern. Critical retrospective of European anthropology]. Moscow: St. Thomas Institute of Philosophy, Theology and History.

Khoruzhiy, S.S. (1998). K fenomenologii askezy [To the phenomenology of ascesis], Moscow: Humanitarian literature Publishing House.

Mortari, L. (2015). K istokam zaboty [To the origins of care], In: My vse v zabote postoiannoy... Kontseptsiia zaboty o sebe $v$ istorii pedagogiki i kul'tury [We are so caring all the time... The concept of care of the self in the history of pedagogy and culture]. Proceedings of the International Conference in the memory of philosopher, sociologist, psychologist G.V. Ivanchenko (1965-2009) (Scientific and research institute of the Higher School of Economics, Moscow, September 9-11, 2015). Edited by M.A. Kozlova and V.G. Bezrogov. Part 1: Postoianstvo prebyvaniia s soboiu [Stability of being with the self] Moscow: Canon+, P. 11-31.

Pichugina, V.K. (2014). Antropologicheskiy diskurs "zaboty o sebe" v antichnoy pedagogike [Anthropological discourse of "care of the self” in ancient pedagogy]. Moscow.

Pichugina, V.K. (2013). Razvitie antropologicheskogo diskursa "zaboty o sebe" v istorii antichnoy pedagogiki [Development of the anthropological discourse of the "care of the self" in ancient pedagogy]. Author's extract from the dissertation for the academic degree od the Doctor of Pedagogy. Volgograd.

Pichugina, V.K. (2013). Antropologicheskiy diskurs pedagogiki. Istoricheskie i teoreticheskie aspekty [Anthropological discourse of pedagogy. Historical and theoretical aspects]. Moscow: FLINTA Nauka, 168 p.

Pogoniaylo, A.G. (2007). Mishel' Fuko. Istoriia sub'ektivnosti [Michel Foucault. History of subjectivity], In: Foucault, M. Germenevtika sub'ekta. Kurs lektsiy, prochitannykh v Kollezh de Frans v 1981-1982 uchebnom godu [Hermeneutics of the subject. Lectures at the College de France, 19811982]. Translated from French by A.G. Pogoniaylo. Saint Petersburg: Nauka, P. 597-662.

Pogoniaylo, A.G. (2009). Tekhnika sebia i filosofiia Novogo vremeni [Technique of the self and philosophy of Modern time], In: Chelovek.RU. Gumanitarnyy al'manakh [Human.RU. Humanitarian almanac]. Novosibirsk: Novosibirsk State University of Economics and Administration, No. 5. P. 67-80.

Poliakova, M.A. (2015). Mesto cura sui v zapadnykh kontseptsiiakh obrazovaniia $(\pi \alpha 1 \delta \varepsilon i ̃$, humanitas, Bildung) [Place of cura suiu in Western concepts of education ( $\pi \alpha 1 \delta \varepsilon \tilde{\alpha} \alpha$, humanitas, Bildung)], In: Vestnik Pravoslavnogo Sviato-Tikhonovskogo gumanitarnogo universiteta. Seriia IV: "Pedagogika. Psikhologiia [Newsletter of St. Tikhon's Orthodox University. Series IV: "Pedagogy. Psychology], Issue 3 (38). P. 80-93.

Smirnov, S.A. (2010). O smysle ontologicheskoy zaboty/raboty (kommentarii na poliakh "Germenevtiki sub'ekta" M. Fuko) [On the meaning of ontological care/work (comments on the "Hermeneutics of the subject" by M. Foucault], In: Vestnik Novosibirskogo gosudarstvennogo universiteta. Seriia: Psikhologiia [Newsletter of Novosibirsk State University. Series: Psychology]. Volume 4, No. 1. P. 74-93.

Smirnov, S.A. (2015). Forsayt cheloveka. Opyty po neklassicheskoy filosofii cheloveka [Human forsight. Experiments on non-classic human philosophy]. Novosibirsk: Offset, $660 \mathrm{p}$.

Solov'iov, A.E. (2006). Istoriko-filosofskiy analiz fenomena "zaboty o sebe" [Historical and philosophic analysis of the "care of the self"]. Author's extract from the dissertation for the academic degree of Candidate of Philosophy. Rostov-on-Don. 
Fasmer, M. (2004). Etimologicheskiy slovar' russkogo iazyka [Etymologic dictionary of Russian languge], in four volumes. V. 2. Moscow: Astrel. Ast, 671 p.

\title{
Антропопрактики заботы о себе: событийность концепта
}

\author{
С.А. Смирнов \\ Новосибирский государственный университет \\ экономики и управления «НИНХ» \\ Россия, 630099, Новосибирск, ул. Каменская, 52
}

В работе вводится понятие антропопрактики как особого рода практики преображения и изменения человека. Понятие обсуждается в рамках концепта и культурной традиции, получивщей название практики «заботы о себе». Понятие антропопрактики рассматривается с точки зрения разных тематических фокусов, то есть топики заботы: онтологический топ, топ дискурса о заботе, топ заботы как практики, топ предмета заботы, топ субъекта заботы. Автор предлагает классификацию антропопрактик, выявляя с точки зрения заявленной топики разные типы предметности и субъектности антропопрактики заботы. В итоге автором показаны пять типов антропопрактики заботы о себе: эпистрофэ, агон, мимезис, когито, автопоэзис. В каждом типе показаны разные идентичности субъекта практики, разные предметности практик и разные телосы, то есть предельные иеели практики. В работе параллельно проводится анализ работ современных авторов, которые занимались анализом и классификачией практик заботы о себе в культуре.

Ключевые слова: антропопрактика, забота о себе, топика антропопрактики, субъект антропопрактики, эпистрофэ, агон, мимезис, когито, автопоэзис.

Работа выполнена в рамках проекта «Построение неклассической антропологии. Новая онтология человека», реализуемого на базе НГУЭУ при поддержке Российского научного фонда (грантовое соглашение № 14-18-03087).

Научная специальность: 09.00.00 - философские науки. 